\title{
NATUREZA E CULTURA NAS ORIGENS DA GEOLOGIA ESPANHOLA*
}

\author{
Horácio Capel** \\ Tradução por André Geraldo Berezuk*** \\ $\&$ \\ J orge Ulisses Guerra Villalobos****
}

\section{RESUMO:}

O prestigiado geógrafo espanhol Horácio Capel relata os tempos polêmicos da Idade Moderna, onde a questão da ciência e da fé, de onde se encontrava a explicação da criação da Terra, era de fundamental importância para o processo de consolidação da ciência moderna, separando as explicações de cunho científico das de cunho teológico, configurando-se esses tempos como tempos de reflexão de idéias tradicionais com a reformulação de seus conceitos. Nesse período revolucionário da história, onde a história da criação do planeta estava sendo questionada, a geologia era um ponto estratégico nos discursos científicos, e o avanço em seus estudos, incluso na Espanha, significava um avanço também nesses discursos, que certamente entrariam em atrito com os relatos sagrados.

\section{PALAVRAS-CHAVE:}

Criação, geologia, Bíblia, ciência, fé.

\section{ABSTRACT:}

The famous spanish geographer Horacio Capel show the hard times of Modern Age, period of core importance for science consolidation process, setting apart the scientific explanations of theological explanations, showing this times like years of reflection of traditional ideas with its concepts reformulations. At this hot period of history, where the story of Earth Creation had been asked, geology was a turning point of scientific speeches and the development of geology studies, included in Spain, means a progress into Creation discuss too, which certainly would shock against Holy Bible words.

\section{KEY WORDS:}

Creation, geology, Bible, science, faith.

A atual divisão entre ciências e humanidades é distinguida tão rigorosamente na opinião pública dos campos do conhecimento que alguns quase chegam a considerar como compartimentos estanques, sendo incluído também o ensino que parece ter aceitado esta divisão, consolidando entre as "ciências" e "letras" um divórcio que resulta, sem dúvida, nefasto. É freqüente encontrar hoje cientistas ignorantes das raízes históricas ou das implicações filosóficas e sociais das teorias que usam, e a humanistas que desconhecem praticamente todo o desenvolvimento da ciência e da metodologia, propagando, inclusive, sua ignorância.

No entanto, esta divisão radical entre ciência e humanidades é relativamente recente, e procede, na realidade, do século XIX. Durante muito tempo, ciências e letras não estiveram tão dissociadas, nem na prática científica, nem nas

*Versão revisada do texto da conferência pronunciada no ciclo "Natureza e cultura no pensamento espanhol", organizado em Barcelona pelo Centro Cultural da Caixa de Pensões, em março de 1986. ** Departamento de Geografia Humana, Faculdade de Geografia, Universidade de Barcelona Doutorando em Geografia pela UNESP - Campus Presidente Prudente. E-mail: aberezuk@bol.com.br ****Professor Doutor pela Universidade Estadual do Maringá - PR. E-mail: jorgegeo@hotmail.com 
instituições acadêmicas. Há de se recordar que o descobrimento e a assimilação da ciência clássica no Renascimento foi uma tarefa de humanistas que combinavam, por sua vez, um saber científico e filosófico; e que durante toda a idade moderna foi muito comum que os intelectuais se ocupassem, ao mesmo tempo, de temas científicos, filosóficos e literários. Todos eles aceitavam crenças que não deixavam influir em suas investigações.

A história da ciência exige cada vez mais uma visão unitária e integradora, e obriga a tomar consciência destas estreitas relações que existiam no passado entre os diversos ramos do saber. Também permite lançar uma visão sobre as relações desse tipo que acontecem na prática científica atual. Mas essa visão, que é algo cada vez mais aceita, é difícil de ser alcançada.

Durante muito tempo, a história das ciências e a história das humanidades têm se formado em campos claramente dissociados. É o que considera um dos fundadores da moderna história da ciência, George Sarton, ao definir, em 1922, o que deveria ser essa nova área de investigação, delimitando-a, claramente, como o estudo do desenvolvimento das matemáticas, da astronomia, da física, da química, da biologia e das ciências da Terra, excluindo dela, explicitamente, as humanidades, a tecnologia e a medicina, esta última em razão de uma tradição histórica independente bem afirmada e institucionalizada.

Na realidade, ao longo do século $X X$, a história da ciência tem sido cultivada essencialmente em duas grandes linhas diferenciadas. Desde 1920 têm existido congressos internacionais de história e medicina, e, desde 1925, congressos de história da ciência com o conteúdo restritivo antes assinalado, que é também, de certo modo, o que se encontra no "Dictionary of Scientific Biography" (p. 1970 e seguintes) ou em obras que levam o título de "Histórias da Ciência", como as de Mieli (p. 1945 e seguintes), Taton (1958), ou, no âmbito espanhol, Vernet (1975).
Essa concepção estreita da história da ciência modificou-se profundamente nos últimos anos. Gradativamente, foi se concebendo como um campo integrado nos diversos ramos do conhecimento científico. Os limites são difíceis de serem mantidos, e as revistas ou as instituições dedicadas especificamente à história da ciência prestam atenção à medicina, uma vez que as revistas e instituições dedicadas à história desta ciência incluem trabalhos sobre a história das ciências físico-matemáticas ou sobre tecnologia. Um exemplo paradigmático de até onde pode chegar hoje este cultivo integrado da história da ciência pode ser o do professor López Piñero, que, desde sua cátedra de História da Medicina na Universidade de Valência, tem realizado pessoalmente, com seus discípulos e colaboradores, valiosas contribuições à história das ciências físico-matemáticas na Espanha. Talvez, por tudo isso, muitos preferem hoje falar de "História das Ciências", para superar essa divisão tradicional, e este é, por exemplo, o nome que adotou uma nova associação criada na Espanha para impulsionar esse campo do saber: a Sociedade Espanhola de História das Ciências, criada em 1974.

Porém, nesta revolução, o mais inovador é a aproximação crescente dos historiadores da ciência até campos que até a pouco se consideravam carentes da prática científica em sentido estrito. Nos referimos diretamente ao campo da filosofia, da história, da literatura e das humanidades em geral. É uma tendência que se comprova facilmente examinando-se os artigos publicados nas revistas especializadas em comunicações apresentadas nos congressos de história da ciência. Como exemplo do que dizemos, pode-se citar uma revista representativa como o "British Journal for the History of Science", de onde foi dedicada atenção recentemente a temas tais como os seguintes: a matéria e o espírito como símbolos na filosofia natural inglesa do século XVIII; atonismo e escatologia: ciência, indústria e ordem social; ou as idéias de Guillermo de Ockham sobre as classificações das ciências.

$$
\text { Paralelamente, nos Congressos }
$$


Internacionais de história da ciência debatemse hoje temas que há dois ou três decênios atrás haviam sido inimagináveis. Assim, por exemplo, no XV Congresso, celebrado em Edinburgh em 1977, de onde esta mudança de tendência começou a receber força. Existiram seções científicas ou simpósios sobre temas como os seguintes: ciência e valores humanos, física e metafísica na revolução científica, histórias das ciências do homem, incluindo a psicologia e historiografia. Mais visivelmente ainda foi possível observar esta evolução no último congresso, o XVII, celebrado em agosto de 1985 em Berkeley, Califórnia, de onde se prestou amplamente, e as vezes apaixonadamente, atenção a temas de epistemologia e filosofia, sociologia das comunidades científicas, inovação tecnológica, implicações sociais da ciência ou às relações entre religião e ciência. Entre as 79 seções científicas que celebraram suas reuniões simultaneamente houve algumas sobre temas como os seguintes: biologia e filosofia nos séculos XVII e XVIII; genética e ideologia da evolução, a ciência social antes de 1800; os fundamentos das ciências sociais, a psicologia, os métodos e conceitos na ciência social, as influências literárias nas ciências físicas, a epistemologia da revolução científica, revolução científica: ciência lógica e cognição, revoluções na ciência, a inovação tecnológica; ciências e crenças religiosas, além de outras dedicadas à medicina e questões etnológicas. Ao mesmo tempo, entre os 21 simpósios organizados havia alguns temas que até há pouco tempo eram escassamente habituais no campo da história da ciência: genética e sociedade, a transmissão do conhecimento natural e implicações sociais, a compreensão e o uso da natureza nas culturas nativas americanas; ciência, literatura e imaginação, sociologia histórica da ciência, metodologia, filosofia e história da ciência, história das ciências naturais e humanas; e ciência e religião.

Os modernos historiadores da ciência se sentem obrigados a incorporar novos temas porque encontram relações insuspeitáveis entre problemas aparentemente comuns. As relações entre o hermetismo e a revolução científica, entre literatura e ciência, entre ciência e arte, entre a história da terra e a história das nações, ou entre religião e ciência, têm sido objeto recente de importantes contribuições por parte de prestigiosos especialistas como F. A. Yates, Pacho Rossi ou Elias Trabulse. Ao mesmo tempo, filósofos e historiadores das humanidades realizam hoje estudos que não podem ser desconhecidos pelos historiadores da ciência para situar corretamente suas investigações: na Espanha os trabalhos de José Antonio Maravall, de José Luis Abellán, de Antonio Bonet ou de Antonio Mestre podem ser bem representativos do que dizemos.

É nesta perspectiva crescentemente integrada da história da ciência e a história das humanidades, de onde se deve situar o trabalho da continuação que se apresenta sobre a natureza e cultura nas origens da geologia espanhola, que sucessivamente iremos expor o conhecimento renascentista da Terra, os estímulos e avanços para um maior conhecimento da estrutura terrestre, o obstáculo do Gênesis e o processo de racionalização da Bíblia, e as hipóteses que foram propostas no século XVII para explicar a formação e estrutura da Terra.

\section{I- O conhecimento Renacentista da Terra}

\section{O Inferno e o Reino de Deus}

De certa maneira, poderia ser dito que para o nascimento de uma reflexão moderna sobre a estrutura terrestre era condição necessária - ainda que, como veremos, não suficiente - que os intelectuais do Renascimento sofressem o impacto da revolução copernicana e da destruição da ordem cosmológica medieval. No hierarquizado e fechado cosmos medieval, a Terra situava-se no centro dos planetas, no lugar mais impróprio do universo. Como escreveu, com certa perspicácia, Lovejoy, criticando certas interpretações apressadas sobre o impacto da revolução copernicana, a Terra "era o fundo da criação em que se fundiam seus elementos mais baixos e suas ações". 
(Lovejoy, 1983, p. 128). No interior dela se encontrava o Inferno, o Averno dos clássicos, que, segundo a tradição clássica e medieval, todavia influente no Renascimento, penetrava por rios subterrâneos ou através de profundos abismos conhecidos popularmente como "bocas do inferno".

Essa é a concepção que aparece no grande poema alegórico de Dante, no que o Inferno adota a forma de um cone invertido e oco, cujo vértice se situa no mesmo centro da Terra, precisamente no ponto mais distante do Reino de Deus. As numerosas especulações que ocorreram no Renascimento (ainda mais por parte de cientistas eminentes como Galileo) ao problema do Inferno e de sua localização e o prolongado eco da concepção de Dante, em particular, mostram que o conteúdo moral da "Divina Comédia" refletia também um difuso estado de opinião sobre esse tema, com indubitáveis conseqüências sobre as opiniões acerca da estrutura inferior do nosso planeta. Opiniões que eram apoiadas pela autoridade da Igreja e que podiam terminar, ainda, claramente demonstradas pelas observações empíricas realizadas sobre o aumento do calor nos poços das minas.

A ruptura do cosmos medieval não podia deixar de afetar a estas crenças. O passo do mundo limitado ao universo infinito (Koyré, 1957) significava a posição do homem no universo, distanciando-o desse centro infernal do universo e permitindo a situação de uma nova dimensão da questão da localização do Universo e do Inferno.

A concepção heliocêntrica situava em uma posição central o Sol, o corpo que mais claramente poderia representar a divindade por ser a fonte de luz e calor e - como escrevia Kepler - o lugar "de que poderíamos julgar que seria merecedor o Altíssimo, se fosse o caso de uma comprovação de uma morada física e de eleger um local de onde habitaria com os bemaventurados anjos" (Lovejoy, 1983, p. 128). No entanto, ao mesmo tempo, a Terra se converteria em um planeta excêntrico, cada vez mais original, segundo avançava a investigação astronômica dos céus e o descobrimento de novos sóis e planetas, e resultava semelhante a outros em que alguns "espíritos" atrevidos prontamente pensaram que podiam também existir criaturas viventes e racionais.

A estrutura interior da Terra, cuja circunferência se conhecia já de forma indubitável no século XVI e cujas dimensões aproximadas também eram conhecidas, podia ser agora objeto de uma indagação na qual não havia que se incorporar, necessariamente, o debate sobre a localização do inferno. Ainda assim este debate apareceu cuidadosamente refletido em alguns dos sistemas que se propunham sobre o mundo subterrâneo, e sendo freqüentemente aludido em obras científicas que se publicaram durante o século XVII. Assim ocorre, por exemplo, na "Nueva Descripción del Orbe de la Tierra" (1681), do geógrafo valenciano José Vicente del Olmo. Em um dos seus capítulos, dedicado à estrutura interior da Terra, presta-se atenção às descrições sobre o interior do planeta que haviam sido realizados por Dante, Morin, Maluenda, Gaffarel e Kircher, autor que será citado e cujas cavernas de fogo recordam em tantos aspectos as figuras místicas de Luzbel e de Plutão. Um desses autores, Jecques Gaffarel, havia publicado, a meados do século XVII, obras como "De cryptis toto orbe celebribus" (1681) e "Lê Monde sousterrein" ou "Description historique et philosophique de tous lês plus beaux antres et de toutes lês belles grottes de la Terre" (Paris, 1654), nas quais dividia as cavernas subterrâneas em cinco classes: as "humanas", habitadas antigamente por gigantes e as cidades subterrâneas; as "bestiais", habitadas por feras e outros animais; as "naturais", como as grutas e outros depósitos internos cheios de distintas substâncias como vapores metálicos, exalações, águas, fogo, gelo e cristais, dentre outras; as "artificiais", realizadas cuidadosamente e artisticamente para o lazer do homem; e as "divinas". Estas últimas se subdividiam, por sua vez, em várias espécies: "angélicas", de onde haviam aparecido anjos, como a gruta do Monte Gargano, célebre pela 
aparição de São Miguel; as "eclesiásticas", essencialmente constituídas por templos escavados em montes ou rochas e as catacumbas; "purgativas", referentes ao purgatório e ao limbo; e as "diabólicas" ou "infernais", situadas nas áreas mais profundas da Terra.

\section{As Fontes do Saber Sobre a Terra}

A reflexão sobre a Terra estava afetada, sobretudo, pela aceitação do relato bíblico da Criação, cuja realidade era indubitável por todos os cristãos. Para os europeus do século XVI, o mundo havia sido criado por Deus em seis dias, era mantido por Ele e seria destruído no Juízo Final. A Terra havia sido criada por Deus para morada do Homem e tudo estava organizado para a conservação do gênero humano, como resultado de um sábio, ainda que às vezes incompreensível, plano divino. Tratava-se de uma concepção antropocêntrica e teleológica em que a existência da Terra somente era concebida se relacionada com a do Homem. A História da Humanidade e a do Mundo estava narrada com a das Escrituras. A primeira consistia em um desenvolvimento linear e progressivo que preparava a vinda de Cristo para redimir o gênero humano. A segunda, a História do Mundo, de fato era inexistente, com exceção da grande catástrofe do Dilúvio, provocada pela cólera de Javé por causa da maldade humana. Com exceção desse fato, a Terra não podia experimentar mudança alguma porque isso teria significado que Deus havia errado na concepção do plano da Criação. Assim, todos os elementos da superfície terrestre, e, por conseguinte, do interior terrestre deviam estar bem dispostos desde o princípio dos tempos, da mesma maneira que se haviam criado, também, todas as espécies animais e vegetais necessárias para a vida do Homem. A antiguidade do mundo, desde o momento da criação, era deduzida pela leitura dos livros sagrados e ainda que a interpretação dos Padres da Igreja pudesse variar em detalhes, em nenhum caso para os homens do renascimento a dita antiguidade superava muito mais do que 6.000 anos.
Ainda que para os cristãos a primeira fonte de conhecimento do mundo fosse a Escritura, também o mundo era digno de ser contemplado, como reconhecimento da obra do Criador. A natureza era um livro cuja leitura elevava a Deus. Por isso a mesma Terra, examinada racionalmente, podia ser objeto de atenção, ainda que geralmente sua observação se fazia com os olhos da exaltação religiosa e com a visão limitada que procedia da mesma narração bíblica.

Porém, os homens do Renascimento possuíam, além das Escrituras e da interpretação eclesiástica, outra base para o conhecimento da estrutura terrestre: a interpretada pela ciência clássica. Aristóteles, Platão, Lucrécio, Plínio, Sêneca e outros filósofos e moralistas haviam especulado na antiguidade sobre a natureza terrestre, e seus escritos, transmitidos em uma outra forma ao longo da Idade Média e editados e estudados avidamente no Renascimento, facilitavam respostas satisfatórias a muitas das perguntas que os europeus do século XVI puderam fazer a essas questões.

Uma parte dessas teorias, as aristotélicas, havia sido bem difundida desde o século XIII e, em boa parte, integrada à ortodoxia cristã. Com exceção da eternidade do mundo, que se opunha à concepção cristãjudaica da criação ex nihilo, o restante das idéias de Aristóteles sobre a física terrestre podia incorporar-se facilmente em uma reflexão científica cristã sobre a Terra, e de fato se integraram plenamente, sendo uma prova disso a obra de São Alberto Magno e de outros cientistas cristãos da Baixa Idade Média.

Estas idéias procedentes da ciência clássica e transmitidas já diretamente, idéias essas influentes nos conceitos dos cientistas cristãos baixo-medievais de tradição platônica ou ripatética, incluíam algumas noções sobre orogenia, circulação das águas, terremotos e vulcanismo, cavernas subterrâneas e períodos de secas e de inundações.

Da ciência clássica procedia também uma 
teoria dos elementos e de suas transformações, assim como uma idéia pouco precisa sobre os limites entre os reinos mineral e vegetal: as rochas podiam ser animadas e experimentar processos de crescimento. A grande cadeia do ser compreendia, mediante valores imperceptíveis, a todos os objetos da natureza. $O$ estudo dos minerais seguia sendo realizado de acordo com a tradição árabe medieval, e remotamente clássica, dos Lapidários. Trata-se de catálogos em que várias centenas de rochas (337 no Lapidário de Alfonso X e uma cifra próxima a essa em outros), se ordenavam segundo os signos do zodíaco e suas virtudes astrológicas, incluindo minerais, corais, algas, cálculos renais e biliares e todos os objetos que poderiam receber de uma maneira ou outra a denominação de pedras.

Os avanços realizados no século XVI não supunham uma mudança decisiva nessa concepção. No Lapidário de Alfonso X, a enumeração e descrição das virtudes das pedras se fazem "conforme a especial cor que têm por natureza e segundo os ensinamentos dos livros dos sábios", com o acréscimo de suas virtudes mágicas e sua simbologia. As descrições se realizam em forma de "histórias" de minerais nas quais a recopilação erudita de toda a informação existente sobre cada um deles se une à descrição de suas características externas, seus poderes mágicos e medicinais, suas características benignas ou malignas. Assim aparece em obras bem significativas, do que Foucault denominou a "epistemologia renascentista", tais como o "De rerum fossilium lapidum et gemarum" (1565) de Conrad Gesner, ou no "Musaeum metallicum" (publicado postumamente em 1648) de Ulisse Aldrovandi, ou na obra, renovadora em muitos conceitos, de Georgius Agrícola, "De natura fossilium". De fato, nessa obra inclui-se descrição de minerais baseada na "imitação" e na "similaridade", discutindo o significado dos nomes que se atribuem às distintas propriedades e utilidades para o comércio e para as artes (Albury \& Oldroyd, 1977). Dentro dessas linhas, pode-se citar, também, com a adaptação espanhola que originou, com relação à obra de Agrícola e outros autores, a afirmação de Bernal Pérez de Vargas: "De Re Metallica", na qual se tratam muitos e diversos segredos do conhecimento de toda a gama de minerais, de como se devem buscá-los, examiná-los, e beneficiá-los, com ainda outros segredos e transformações notáveis (Madrid, 1569) ou o "Libro de las virtudes e propriedades maravillosas de las piedras preciosas" (1605) de Gaspar de Morales, livro este que foi proibido pela Inquisição.

\section{II- Estímulos e Avanços para um maior Conhecimento da Estrutura Terrestre}

As grandes transformações econômicas, sociais e científicas que se produziram a partir do século XVI não podiam deixar de afetar também o desenvolvimento da reflexão sobre a estrutura terrestre, sua história e seus componentes físicos. No entanto, o problema da profundidade desse impacto para o desenvolvimento de uma reflexão científica moderna no campo do que logo se chamou "geologia" estão ainda por ser determinado de forma convincente. A impressão que se tem é que os avanços não foram particularmente significativos, com exceção do campo da mineração e metalurgia, e que o obstáculo que o Gênesis impôs impediu o avanço de idéias globais verdadeiramente alternativas às concepções existentes.

\section{O Descobrimento do Novo Mundo}

Temos de mencionar necessariamente, em primeiro lugar, o impacto que sobre este tipo de conhecimentos puderam ter os grandes descobrimentos geográficos. Novos ciclos, novas terras e novos mares são conhecidos pelos europeus a partir do século XVI e não há dúvida de que isso deveria contribuir a modificar profundamente a imagem da natureza terrestre. Assim ocorre ao que se refere ao conhecimento geográfico da superfície terrestre, da topografia e das características gerais dos territórios e das populações no Novo Mundo e em outras regiões agora visitadas. Todavia, ainda deve-se estudar, 
qual foi a contribuição precisa dos descobrimentos geográficos ao desenvolvimento das teorias "geológicas".

A investigação das novas terras conhecidas pelos espanhóis iniciou-se imediatamente depois do descobrimento, originando rapidamente as obras em conjunto como as de Gonzalo Fernandez de Oviedo (1519 e 1526) ou a de Francisco López de Gómara (1552). Mais tarde foi decididamente impulsionada pela obra do cosmógrafo Juan López de Velasco e, em particular, pelas instruções que redigiu em 1577 e nas que se enumeravam cuidadosamente as cinqüenta questões que tinham de ser prioritariamente recolhidas nos informes elaborados sobre os diferentes territórios americanos e asiáticos. Tudo isso foi definindo um gênero que se conhece como "crônicas das índias" e que constituiu uma contribuição essencial ao conhecimento público das novas terras.

A leitura dessas crônicas das Índias, assim como dos relatos de viagens de portugueses e de outros europeus, se, por um lado, impressiona pela riqueza das novas notícias e pelo espírito aberto e audaz que demonstram os narradores, por outro, chama a atenção pela escassez ou ausência de interpretações novas sobre a estrutura terrestre. As coreografias e as histórias naturais das Índias interessam, desde logo, pelo variado e fascinante mundo vegetal e animal, e surpreendem pela habitabilidade da zona tórrida. Explicam, periodicamente, as características térmicas, as chuvas e os ventos (tão diferentes aos das regiões européias), enumeram os rios e lagos; descrevem as correntes marítimas, o fluxo e refluxo dos oceanos, as selvas impenetráveis e as qualidades de cada território para a habitação humana.

Desde o ponto de vista "geológico", encontramos, também, nessas obras notícias valiosas, ainda que limitadas essencialmente a esses três aspectos: 1) a topografia, e em particular, a assombrosa altura das montanhas;
2) as riquezas minerais e a forma de explorálas; e 3) o vulcanismo e os terremotos. A obra "La Geografia y Description Universal de las Índias" (1571-1574) do cosmógrafo Juan López de Velasco, a "Historia del Nuevo Mundo" (1653) de Bernabé Cobo e a "Histórica relação del Reyno de Chile" (1646) de Alonso de Ovalle, podem ser um bom exemplo do que dizemos, ainda que, sem dúvida, o tema mereça uma maior atenção, que não podemos dedicar aqui.

As concepções sobre a natureza mineral se viam afetadas, nesses autores, pelas idéias dominantes. As influências astrais podiam ser utilizadas para explicar a abundância de metais que existiam em certas partes das serras andinas, tal como diz Juan López de Velasco, uma das grandes personalidades científicas de sua época:

A causa de haver mais ouro e metais nas áreas dessas serras voltadas ao ocidente, parece ser, pelo fato dos metais se formarem nas profundezas da terra, de onde a terra é mais pura e quase rochosa, e pela maior parte de sua superfície ser estéril e pelada, provém da pouca umidade que concede a área, como por parte daquelas serras que estão mais descobertas e sem vegetação, por serem mais elevadas, estão mais dispostas a receber a influência do céu, manifestando-se mais prontamente a elas. A outra parte da cordilheira que mira o oriente, desde as províncias de Quito até o estreito (de Magalhães), por constituir toda a terra plana, encorpada e cheia de árvores e pântanos, não parece tão disposta a formar metais, sendo que no que foi descoberto até agora no Rio da Prata e do Brasil não se têm chegado notícias da existência de metais nenhum que sejam proveitosos para extração (López de Velasco: Geografia y Descripcíon Universal de las Índias, 1571 - 1574, porém inédita até fins do século XIX; ed. 1971, p. 12).

Durante muito tempo as relações entre os distintos reinos da natureza se seguiram idealizadas segundo analogias que supõem a 
aceitação de uma ordem de correspondências em todo o mundo criado. Assim, Acosta, por exemplo, vê as relações entre os distintos reinos da natureza:

Os metais são como plantas encobertas nas profundezas da terra, e possuem alguma semelhança no modo de produzir-se, pois se vêm também seus ramos, e como tronco de onde saem, que são as veias maiores e menores que entre si têm notável enlace e combinação, e que de alguma maneira parece que crescem os minerais como plantas. Não porque tenham verdadeira vida interior, pois isso é somente proveniente de plantas verdadeiras, mas porque de tal modo se produzem nas profundezas da terra por virtude e eficácia do sol, e de outros planetas, que no decorrer do longo tempo vêm se acumulando, e quase se propagando. E assim, como os metais são como plantas ocultas da Terra, assim também podemos dizer que as plantas são como animais fixos em um lugar, cuja vida se governa do alimento que a natureza lhes provém em seu próprio nascimento (Acosta: História natural e moral de las Índias, 1590, L. IV, cap. I).

A partir daqui, Acosta deduz um sistema de relações "ecológicas" entre os elementos dos distintos reinos da natureza, uma espécie de cadeia eutrófica renascentista que expressa a grande cadeia do ser e cuja maravilhosa ordem de equilíbrio demonstra a ordem divina da natureza, permitindo o louvor e a glória ao Criador:

De sorte que a terra estéril e rude é como matéria e alimento dos metais, a terra fértil e mais desenvolvida é alimento das plantas; as mesmas plantas são alimentos dos animais; e as plantas e os animais são alimento dos homens, servindo sempre a natureza inferior para sustento da superior, e a menos perfeita subordinando-se a mais perfeita (Acosta, (bidem).

Esta visão tradicional do reino mineral não é exclusiva do Padre Acosta, mas aparece, também, em outros autores. Seu colega, o
Padre Bartolomé Cobo, dedica grande atenção no livro III de sua "História del Nuevo Mundo" (1653) aos minerais, em um esquema tipicamente renascentista que abarca o estudo de rochas, minerais, vegetais petrificados, pedras encontradas nas vias digestivas e urinárias de seres vivos e pérolas, explicando a gênese de cada uma e suas aplicações e usos na medicina e na indústria.

Relendo as crônicas das Índias, e as relações de viagens, têm-se a impressão de que seus redatores, como homens de seu tempo, aceitavam as idéias dominantes sobre a natureza física terrestre, sem questioná-las em seu aspecto fundamental, já que esse não era o objetivo de suas obras. Suas grandes doses de observação e seu espírito livre e audaz se voltavam, sobretudo, à narração das riquezas naturais e maravilhas das novas terras, em uma descrição que não freqüentemente se elevava a indagações de caráter geral sobre a estrutura da Terra ou sobre as mudanças que poderiam haver sido produzidas sobre elas.

É visto que essas indagações parciais sobre a altura e as características de montes e vales, sobre os repetidos e sempre impressionantes fenômenos vulcânicos e sísmicos, sobre as jazidas minerais e a forma de exploração, sobre a circulação das águas terrestres, sobre a configuração das costas e sobre outros aspectos de caráter geomorfológico ou mineralógico têm podido supor para o desenvolvimento de uma reflexão geológica da Europa. É urgente que os historiadores da ciência, espanhóis e hispanoamericanos, iniciem estudos sobre essas questões que tanto importam à história da ciência européia.

Mesmo com o fato de ter sido muito o que esses narradores abordaram, não será deles que poderemos esperar as maiores inovações, a não ser nas atrevidas conjecturas e hipóteses geológicas que alguns formularam para resolver problemas como a localização do paraíso terrestre, o dilúvio ou o povoamento americano, interessavam vivamente aos homens 
da época. O exame que se tem realizado da obra do padre Acosta e de outros autores a propósito do povoamento americano me isenta de tratar mais amplamente o tema nesta conferência.

\section{A Resolução de Problemas Práticos}

Em uma enumeração dos fatores que puderam incidir no desenvolvimento da reflexão "geográfica", às notícias sobre as terras novamente descobertas, que permitiram ampliar a imagem da natureza terrestre e o aparecimento de novos problemas científicos, uniu-se uma série de estímulos que procedem dos esforços para resolver diversas necessidades práticas.

Neste sentido, devem ser citados aqui os trabalhos sobre a prospecção de fontes e sobre o problema da circulação fluvial; os estudos sobre as águas termais e sobre balneários, que interessavam amplamente por sua aplicação médica, e que podiam dar origem a indagações sobre a origem de ditas águas, a construção de canais, portos e fortificações, que incidentalmente podiam provocar reflexões sobre a dureza dos materiais rochosos ou a evolução das linhas de costa. Outra indagação é com a preocupação pelo aumento dos rendimentos agrícolas, que se introduz nos livros de agricultura, como, por exemplo, a Obra de Agricultura, de Gabriel Alonso de Herrera (1513), a discussão sobre os sinais para se encontrar água, a qualidade das terras, assim como os preceitos para conhecer sua fertilidade ou infertilidade ou para melhorá-las caso necessário.

Porém, sobretudo, há que citar, necessariamente, as investigações sobre mineralogia e metalurgia, enquadradas entre a mineralogia, a geologia, a alquimia e a química moderna. Nelas se encontra, sem dúvida, uma importante linha de reflexão sobre a estrutura da terra e a constituição de seus elementos. O problema da geração dos metais, a busca de procedimentos para descobrir as jazidas desses minérios e a exploração de novos métodos para o benefício desses metais deram origem ao grupo mais importante de obras de caráter puramente "geológico" que podem ser citados do século XVI.

Na Espanha, o florescimento desse tipo de obras foi abundante e tem sido devidamente levantada, já que, na realidade, o aspecto da história de geologia hispânica atraiu até agora a maior atenção dos especialistas (Bargalló, 1955; Vernet, 1975, 100 ss; López Piñero, 1979, 259 ss). Por sua importância econômica e política, as riquezas dos metais preciosos do Novo Mundo e as minas de mercúrio espanholas e americanas foram objeto de numerosos estudos, aos que se uniram outros de caráter geral, de títulos bem significativos: "Relacíon e testimônio del nuevo benefício de metais" (1587?) de Carlos Corso; "Del benefício de las minas de azougue" (1588) de Bachiller Garci-Sanchez; "Benefício común o Directorio de beneficiadores de metais e Arte de ellos" (1638) do licenciado Fernando Montesinos; "Arte de los metales, em que se enseña el verdadeiro benefício de los de oro e plata por azougue, el modo de fundirlos todos e como se han de refinar e apartar unos de otros" (Madrid, 1640) de Álvaro Alonso Barba; "Informe del nuevo benefício que se há dado a los metales ordinários de plata por azougue, e philosophia natural a que se reduce el método y arte de la minéria" (México, 1643) de Luis Berrio de Montalvo; "Tratado de la cualidade manifesta e virtud del azougue, Ihamado comúnmente el Mercúrio, y por otro nombre el Argentum vivum" (México, 1649) de Hernando de Becerra; "De la generacion de los metales e sus compuestos" (1661) de Juan Ramón de Valdárrago; "Notícias del mineraje de Índias e de las minas que hay en Espana" (1673?) de Fernando de Contreras; "Forma del nuevo benefício de los minerales de plata" (Lima, 1676) de Juan del Corro Segarra; "Directorio del benefício del azougue de metales de plata" (1690) de Juan de Alcalá y Amurrio. Estes trabalhos, enumerados a partir da relação que fez Menéndez Pelayo em "La Ciência Española" (III, 240 ss) são alguns dos que publicaram ao longo dos séculos XVI e XVII e provam a continuidade e riqueza desta tradição 
minero-metalúrgica no mundo hispânico.

Uma boa parte desta produção técnicocientífica pode ser valorizada como expoente de um novo tipo de investigação, próprio da revolução científica do século XVII, pela capacidade de observação de que dão mostra seus autores; pela experimentação repetitiva, precisa e controlada; pela crítica da erudição inútil; pela preocupação pelos resultados e viabilidade técnica dos procedimentos sugeridos. Mas apesar da importância de todos esses trabalhos e dos avanços técnicos a que deram lugar, não é deles de onde surgiu uma melhor compreensão da estrutura terrestre nem o que permitiu descobrir a história da Terra. Seus autores eram técnicos práticos, que usavam métodos empíricos, sem uma base teórica clara, e que em ocasiões estavam relacionados com uma tradição alquímico-hermética, de grande influência no século XVII. Podiam aceitar, como faz o mesmo Alonso Barba, uma das figuras mais importantes desta linha de trabalhos, a existência de uma energia ativa que gera as rochas, a presença de seivas petrificantes, a influência dos raios de sol na geração dos metais, a formação de filões como resultado da força combinada de um calor interno e de outro astral ou exterior. Em algum caso, partindo de premissas alquímicas, as idéias sobre a transmutação dos metais podiam guiar algum de seus experimentos, ainda que mostravam atuar como homens de uma nova época, ao ser capazes de reconhecer, como afirma o mesmo Barba, que os resultados obtidos se aportavam dos pressupostos iniciais. (Capel, 1980, 10 ss.)

Não há dúvida de que, em conjunto, todos esses trabalhos que supunham avanços técnicos concretos permitiram avançar no conhecimento da natureza terrestre e abriam assim o caminho até o desenvolvimento da moderna geologia. Mas em sua concepção global acerca da Terra, estas obras podiam ser muito pouco renovadoras, e seguiam mantendo, até o avançado século XVII, idéias aristotélicas ou alquímico-herméticas. Assim ocorre, por exemplo, na obra citada de Berrio de Montalvo, alto funcionário no México e doutor pela sua universidade, na qual aceita grande número de princípios alquímicos, assim como a influência dos astros na geração dos metais, idéia esta que já havíamos encontrado em López de Velasco durante o século anterior.

Desde muitos pontos de vista, essas obras técnicas não diferiam muito das concepções aceitas por outros autores de formação humanística e que dedicavam eruditas hipóteses ao problema das riquezas minerais da Península. No "Tratado curioso: Descripcíon breve de las antiguas minas de Espana" (1624) redigido pelo nobre Alonso Carrillo Laso, obra bem típica da erudição humanista, o autor considera que a maior parte da Espanha é "monstruosa, estéril e delicada, de ares muito puros", meio que considera ideal "para que o movimento, e luz dos céus e das estrelas atuem, e natureza própria para os metais" (Ed. 1770, pág. 199). Sua concepção sobre a geração dos metais cai bem em manifesto neste parágrafo, que cremos valer a pena reproduzir, já que se constitui a única obra geral publicada sobre a mineração espanhola durante o século XVIII:

De tudo o que havemos dito se observa, que donde houve minas antigamente, podem ser encontradas agora; porque a mesma disposição tem a terra, que as produziu. Terra que recebeu o ponto de sua formação, dado que se há uma mesma disposição se dará uma semelhantíssima obra, pelas causas universais do movimento e da luz. Pois, recebendo a influência da luz, segundo o modo de que se recebe, sempre se gerará ouro de onde houve natural disposição, de modo que, introduzido o Sol, forme os metais. Assim nas circunstâncias do que há, prevendo-as e sazonando-as, nunca está ociosa a natureza, e digerindo os metais, já que também há lugares onde não os existem, atua em algumas partes com mais dificuldade, mostrando-se o meio a presença de certos raios em vista, determinando, ou volvendo esses mesmos raios propícios à formação dos metais, ainda que seja depois de muitos anos (Carrillo Laso, 1624; ed. de 1770 junto com a obra de Álvaro Alonso Barba, pág. 225-226). 
A tese da influência astral na geração de metais e minerais se manteve durante uma boa parte do século XVI, combinando-se com uma teoria alquímica das reações, e com certos aspectos da concepção aristocrática. Todavia, nas décadas finais do século XVI, se podia escrever que nesse processo os astros e os céus concorriam como princípio universal e remoto, o fogo subterrâneo como causa próxima e presente, os vapores sulfúreos, salinos e de mercúrio como causas materiais, sendo a causa final a utilidade dos metais e minerais para as necessidades do gênero humano. O mecanismo, através do qual se produzia a geração dos metais e minerais, pôde ser escrito assim, como o que realiza um geógrafo espanhol já citado anteriormente:

Na massa deste globo terrestre está concentrado um jogo harmônico, que participando das elementares qualidades e reduzido a vapores com relação à força dos fogos subterrâneos, e distribuído pelas veias e cavidades da terra, de onde haja matriz proporcionada, ali se recolhe e fica por longo tempo, até converter-se em aquele metal mais próprio e adequado ao receptáculo e às glebas terrestres de onde se extrai, que originam tanta variedade de pedras e metais, cujas formas se reputam por substâncias, distintas entre si especificamente. Do que se refere, não é levada em consideração a mistura dos Elementos; o frio, o calor, a umidade nem a falta desta (que desta maneira se distinguiriam entre si acidentalmente), mas daquele conjunto de vapores, que lhes originou, que segundo as combinações de seus elementos, são tantas as suas variações (José Vicente del Olmo: Nueva descripcíon del Orbe de la Tierra, 1681, págs. 35-36).

As obras gerais se seguiram mantendo concepções tradicionais sobre a geração dos minerais. Pode-se indicar que os trabalhos dos técnicos não eram utilizados pelos eruditos da época, mas também que as idéias dominantes sobre este tema não sofreram modificações importantes ao longo do século XVII em nosso país. Em qualquer caso, necessitam-se novas investigações que, na direção das já iniciadas por Eugênio Portela, mostrem a relação entre, por um lado, o trabalho empírico no campo da mineração e metalurgia e, por outro, a elaboração de uma teoria geral sobre as jazidas minerais e, mais amplamente, sobre a constituição da Terra.

A impressão que se têm é que os trabalhos empíricos realizados pelos técnicos especializados necessitavam de concepções globais prévias para poderem ser interpretados. Em particular, isto é, sem dúvida, assim no que se referem às observações, que davam conta das mudanças na superfície terrestre, elas teriam que vencer previamente um fundamental obstáculo: a visão da terra que se originava da narração do Gênesis. Voltaremos agora novamente a ela nossa atenção.

\section{III- O Obstáculo Genesis e o Processo de Racionalização da Bíblia}

A interpretação adequada das observações empíricas que se iam realizando sobre a natureza terrestre e a possibilidade de elevar-se a uma visão global de sua estrutura e de sua evolução chocava-se com o obstáculo fundamental da narração bíblica da criação. O desenvolvimento da moderna geologia científica promoveu um indispensável debate que permitiu a passagem de uma concepção antropocêntrica, teleológica e providencialista à outra que aceita a idéia de mudança e evolução, que nega o finalismo e que aceita as leis da física para explicar a história e a estrutura da Terra. E esse debate ia unido, em boa parte, ao processo de racionalização do relato bíblico.

Durante a idade moderna, a ideologia, a teleologia e a ciência natural estavam, todavia, intimamente relacionadas, e as idéias de Deus, de seus atributos e perfeições impunham evidentes questões na concepção científica do mundo natural. Sem dúvida, ao longo desses séculos, o mundo da ciência e o da fé iam se separando e o estudo deste divórcio, assim como o processo de racionalização crescente da 
visão do mundo, é um dos temas mais interessantes da evolução do pensamento científico moderno. Mas se trata de um processo que se efetuou lentamente e de forma laboriosa, e que foi, por vez, muito desgastante para a consciência de muitos cientistas que eram profundamente crentes e que viam aparecer às vezes sérias dificuldades para integrar os dados da observação empírica no relato oferecido pela Escritura sobre a História da Terra.

Desde logo, o processo pôde avançar com ritmo distinto nos países europeus a partir do momento em que a unidade da Cristandade ocidental se viu ameaçada pela Reforma Protestante. O êxito espetacular da ciência moderna nos países afetados pela Reforma podia levar a pensar que existe uma relação direta do sucesso científico, contrapondo-se uma teologia protestante que favorece a reflexão científica e outra católica que atuaria, com a Contra-Reforma, em sentido oposto. O problema é, sem dúvida, mais complexo porque imediatamente seriam introduzidas uma grande diversidade de correntes ideológicas no cristianismo reformado contra as oposições teleológicas que existiram por debaixo da aparente uniformidade, no âmbito da contrareforma eclesiástica, típica do pensamento reformado, favorecendo, sem dúvida, a reflexão científica. Porém, desde logo, as crenças religiosas seguiam presentes, e em alguns casos o peso da narração bíblica podia ser ainda muito maior que nos países católicos, de onde sempre estava aberta a possibilidade de uma interpretação alegórica por parte da Igreja. A opinião de Francis Bacon sobre a nefasta mescla de teologia e filosofia natural e sobre os efeitos perniciosos que teria na ciência a "atenção religiosa cega e imoderada" (Novum Organum, 1620, LXII e LXXXIX) não era, sem dúvida, compartilhada por todos no mundo reformulado, como mostram muitos episódios da história intelectual e política desses países.

No mundo católico da Contra-Reforma, a unidade e a coesão estavam asseguradas pela autoridade de Roma. Porém, o monopólio era mais aparente que real e era percebido somente ao inimigo exterior. Debaixo desse aparente poder existiam tensões agudas e confrontos que refletiam, além de uma luta pelo poder, tradições teleológicas bem contrapostas e cujas raízes podiam remontar a desde os primeiros séculos do cristianismo. Correntes que haviam tido grande vigor no passado, como também correntes místicas e iluminadas, podiam ficar oficialmente banidas, mas permanecer ativas na ilegalidade, com uma grande força que dava lugar, em ocasiões extremas, a processos clamorosos. Porém, sobretudo, as distintas ordens religiosas podiam ter, desenvolvidas, tradições teleológicas diferenciadas, e neste sentido parece importante a contraposição entre essas ordens que elaboraram sua teologia seguindo a tradição platônica, através da influência de Santo Agostinho (agostinos, franciscanos e capuchinhos) e as que receberam um impacto decisivo do pensamento de Aristóteles, tal como foi integrado no cristianismo do século XIII (essencialmente os dominicanos).

No mundo católico da Contra-Reforma, a interpretação do relato bíblico não era sempre homogênea e sem polêmicas. Não podiam ser desconsiderados quinze séculos de debate teológico, que havia dado lugar a uma rica literatura de caráter exegético, em particular referente ao relato da Criação. As perguntas que eram feitas eram numerosas, desde a razão pelo qual Deus havia criado o mundo em seis dias até mesmo o sentido pela seqüência. Estas são as questões que abordam o que se conhece hoje como literatura hexameral, por referir-se aos seis dias da Criação. Essa hermenêutica produzia resultados muito diversos. Às vezes conduzia à interpretação natural que explicava as distintas fases da Criação através de fenômenos naturais conhecidos. Noutras se apoiava em alguma teoria místico-matemática dos números, e considerava a ordem numérica dos elementos sucessivamente criados nos seis dias, para obter daí uma interpretação de seu sentido: como afirmou Filón de Alexandria no século I, combinando a filosofia religiosa do neopitagorismo e a exegese judaica. 
Também podia realizar-se uma analogia entre a Criação e a atividade do artesão que realiza sua obra lentamente, e aproveitar a ocasião para moralizar sobre o valor do trabalho bem feito e sobre a necessidade de imitar o Criador.

Apoiando-se no texto da Escritura, os primeiros Padres da Igreja afirmaram, também, claramente, que o homem pode reconhecer o Criador no mundo. Esta posição conduzia, necessariamente, a respeitar e observar a natureza, a qual era considerada como um livro cuja leitura elevava à Deus. A metáfora do livro aparece desde os primeiros tempos do cristianismo, e foi desenvolvida, entre outros, por São João Crisóstomo e Santo Agostinho, por São J oão Damasceno, no século VII, e por São Isidoro de Sevilha. O grande livro da revelação divina, a Bíblia, podia ser assim complementado por outro livro existente, o da natureza. Sem dúvida, esta não revelava tudo sobre Deus, que é um ser transcendente, mas por sua vez, podia ser lida por todos os homens, incluso os infiéis, com somente a sua própria razão. Através da contemplação e estudo da natureza, o cristão podia encontrar um caminho até a divindade e seus atributos, fortalecer sua fé mediante a contemplação das obras de Deus.

A larga tradição de especulação teológica no meio do cristianismo explica que, aceitando basicamente a validez do relato bíblico, os distintos autores puderam elevar-se a interpretações racionais sobre algumas questões do mesmo, as quais podiam dar lugar a resultados combinadamente diferentes, de grande interesse, no que aqui nos importa para a história da geologia. A negação do caos original e a afirmação de que Deus não faz nada em vão, nem tem necessidade de mudar seus planos, conduz a aceitar que a Terra havia sido criada de uma vez, com todos os atributos necessários para seu funcionamento e para a vida do homem. De todas as formas, apesar da declaração de princípios sobre a imutabilidade da natureza terrestre, a descrição dos primeiros tempos da criação podia fazer avançar alguns autores a suposições que implicavam, de alguma maneira, a aceitação da mudança na superfície terrestre.

O intento da racionalização e explicação natural da narração do Gênesis foi realizado entre os séculos XVII e XVIII, com a participação de diversos eruditos espanhóis, semelhantemente ao que contemporaneamente empreenderam outros intelectuais europeus, aos quais aludiremos mais adiante nesta mesma obra, e têm em comum com eles a particularidade de que eram clérigos, literatos, historiadores e humanistas. Apesar de sua escassa consistência científica, que autores mais preparados cientificamente se apressaram a pôr em evidência, essas interpretações eruditas apresentam um grande interesse, já que contribuíram de forma importante a questionar o relato bíblico e a difundir entre os europeus a idéia de que a Terra têm uma história que é diferentemente narrada na Escritura.

Isto representava uma grande novidade. Essa idéia revolucionária, do mesmo modo que o do retorno cíclico ou da eternidade do mundo, era inaceitável para o pensamento cristão. Para o cristão a natureza era essencialmente estática e imutável, tal como se deduz na Bíblia. O que a Idade Moderna assinala a isso é o descobrimento da história da Terra. Ao longo do século XVII os europeus vão descobrindo que a natureza tem uma história, e que essa história não é somente narrada na Bíblia, mas também que aparece nos vestígios dos fósseis e na disposição das rochas. Mas entre essas idéias, o relato bíblico e a história natural, não podiam existir discordâncias (Rossi, 1979), e por isso, o esforço inicial de muitos cientistas durante esse período dirige-se a interpretar a Escritura de modo racional para fins naturais, de forma que fosse possível admitir as conclusões e os resultados obtidos a partir da observação natural. Esta interpretação era particularmente necessária naqueles pontos acerca dos quais a Sagrada Escritura não facilitava respostas suficientes. Nem todos aceitavam a necessidade desta racionalização, que para alguns era altamente perigosa. 
Esta atitude de negar as intenções de interpretar em fins naturais o que é narrado na Bíblia apareceu tanto em países católicos como nos protestantes, e era defendida tanto por pessoas de comportamento tradicional ou reacionário, como por cientistas de vanguarda e crentes que se esforçavam por separar cuidadosamente os campos da fé e da ciência. Em qualquer caso, as discussões sobre tudo isso estiveram profundamente influídas por idéias teológicas e filosóficas de caráter geral, mas guiadas pela observação direta da natureza.

\section{IV - Pensando em Mundos Imaginários}

Apesar de todas as limitações derivadas da narração do relato bíblico da Criação, no século XVII pôde-se desenvolver uma reflexão científica que ofereceu alternativa nova e imaginativa à narração do Gênesis. Algumas delas se encontram em relação com as evoluções mais significativas da revolução científica: renunciam à razão teológica e conduzem a aplicar os princípios da mecânica ao estudo da Terra e da unificação da física celeste e terrestre. A obra de Descartes constitui, neste sentido, um fato particularmente decisivo. Outras, ao contrário, se mantêm próximas ao relato bíblico, mas se esforçam em realizar uma interpretação racional do mesmo tendo em conta os princípios da nova física e da história natural. Um terceiro grupo, de mentalidade tipicamente humanista, encontra dificuldades graves nos textos sagrados e se esforça por propor interpretações novas e imaginativas dos mesmos. Em qualquer caso, ao longo do século XVII, os europeus puderam dispor de novas hipóteses que apresentavam uma interpretação global da estrutura e da evolução da Terra. Aludiremos às diversas linhas de reflexão.

\section{O Sistema de Descartes}

A ousadia intelectual de Descartes deve ser devidamente valorizada também neste campo do conhecimento científico. Em seu "Traité du Monde", publicado em 1631 e resumido parcialmente em outras obras posteriores, Descartes se atreve a imaginar, usando as leis da física, a forma como Deus havia criado o mundo, e os aspectos necessários da configuração que chegou a ter.

Com o fim de expor suas opiniões com maior liberdade e para não ter que refutar as idéias comumentemente admitidas sobre a Terra e o Universo, Descartes imaginava o que ocorreria se Deus decidisse criar um mundo novo reunindo nos espaços imaginários suficiente matéria para compô-lo e, depois de discutir a forma diversa e sem ordem das diversas partes dessa matéria até formar o confuso caos original que estava na origem da criação, decidira deixar criar a natureza de acordo com as leis que o mesmo havia estabelecido.

O resultado desta decisão havia de ser um mundo como realmente é, submetido a leis da natureza que podem ser provadas através da idéia da infinita perfeição divina, cuja validez é tão universal que "ainda que Deus houvesse criado vários mundos, não poderia originar-se um em que não se concretizasse".

Descartes mostra como nessa criação "a maior parte da matéria deste caos devia dispor-se e relacionar-se em virtude de tais leis de uma forma tal que era similar a de nossos céus; como alguma das partes desta matéria devia compor uma terra, alguns planetas e constelações". Tudo o que se deduzia de seu modelo, atuando de acordo com as leis da física, se assemelhava ao que se podia observar no mundo real existente. Enquanto ao nosso planeta, explica que "todas as partes da matéria tenderia exatamente do centro da Terra", sem que para isso fosse necessário, contrariando a opinião de Aristóteles, que Deus houvesse conferido à matéria nenhuma propriedade de gravidade. Em sua teorização, a Terra adquire uma forma esférica compacta e a existência de água e de ar sobre sua superfície deve dar lugar necessariamente a um fluxo e refluxo "semelhante em todas as circunstâncias ao que 
se observa em nossos mares", sendo produzida, portanto, também uma certa corrente destes elementos do oriente ao ocidente, similar ao que se observa nos trópicos. Da mesma forma, nessa criação realizada de acordo com as leis da física, "as montanhas, os mares, as fontes e os rios podem formar-se naturalmente", os metais podem se formar no interior da terra, por efeito das forças internas e não como resultado de influências siderais, e os compostos se produzem a partir da mesma substância contida na Terra. Deus havia criado o mundo com uma força que era a mesma com que o conservava: "portanto, ainda que se houvesse dado, no início, outra forma que a do caos, havendo estabelecido as leis da natureza e prestando-Ihe seu curso para a criação tal como é habitual, pode opinar-se, sem distorcer o milagre da criação, que todas as coisas que são puramente materiais haviam podido com o tempo chegar a ser tal com agora as vemos" (as citações procedem do Discurso del Método, 1637, $5^{\mathrm{a}}$ parte).

Estamos aqui muito distantes do relato do Gênesis, e não existe neste trabalho a menor preocupação por partir deste relato para compreender a formação de nosso planeta. Como escreveu um contemporâneo seu que conheceu pessoalmente, Burman, Descartes "havia renunciado ao propósito de mostrar como sua filosofia era compatível com a forma em que se descreve a criação no Gênesis", mais ainda, não queria dar explicações "sobre a compatibilidade entre o relato bíblico e a física" e havia "decidido deixar esse tema aos teólogos", considerando que a narração da Escritura era de natureza metafórica. Na obra de Descartes se expressa de maneira decisiva a separação entre o mundo da física, próprio da reflexão científica, e o da religião, próprio das crenças e das interpretações teológicas; sendo que a narração da criação do mundo que dava ao Gênesis pertencia a esse campo alegórico reservado aos teólogos.

Porém não pôde escapar totalmente a antigas idéias sobre a estrutura interior, como, por exemplo, as que, desde tempos atrás, afirmavam a existência de vastos depósitos de água sobre os quais flutuavam os continentes, ou as que aceitavam a conexão das águas terrestres e marinhas através de uma circulação geral que era semelhante à dos organismos vivos. Tampouco pôde eludir a narração do Gênesis, que para os homens do século XVII refletia, ainda mais da palavra de Deus, o relato mais confiável sobre a história da Terra. O dilúvio, por exemplo, não desapareceu de suas explicações.

Efetivamente, o globo terrestre havia-se formado segundo as leis da física e, seguramente, havia sido primitivamente de natureza semelhante à do Sol, sem diferir deste mais do que em seu menor tamanho (Descartes: "Lês príncipes de la Philosophie", IV, p. 44 e 45). Posteriormente, se produziu um esfriamento que se iniciou nas capas superficiais e avançou até o interior, de onde se manteria o estado de calor e fusão da estrela primitiva. Na superfície apareceriam várias capas cada vez mais recentes e depósitos interiores de água que formariam uma espécie de oceano interior sobre os quais flutuavam as crostas mais superficiais. No processo de resfriamento, a crosta superficial sofreu contrações e deslocamentos que formaram o relevo dos continentes e que permitiram a saída das águas interiores. Fenômenos como o dilúvio poderiam assim ser explicados fisicamente, sem necessidade de acudir a um milagre e sem contradizer as leis da natureza.

A obra de Descartes representa, sem dúvida, um mito essencial ao caminho à moderna geologia. A partir dele existe um sistema racional, apoiado pelas leis da física, que permite explicar a formação da Terra. Supõe uma alternativa científica ao relato da formação do mundo facilitado pelo Gênesis. Descartes critica também o finalismo e não aceita que tudo havia sido criado por Deus para uso exclusivo do homem.

Porém a possibilidade desta reflexão livre e imaginativa sobre a Terra foi negada nos países católicos por causa da pena imposta a Galileu em 1632. Descartes decidiu então não 
publicar seu "Traité du monde", em que desenvolvia amplamente suas idéias, e se limitou a resumir alguns pontos de suas obras posteriores. Porém nem sequer essa autocensura e sua indubitável ortodoxia católica foram suficientes: em 1663 Roma colocou seus escritos no Índice. Os problemas nos países protestantes não faltaram, e na Holanda, que de fato era sua segunda pátria e de onde tinha grande número de amigos e admiradores, sua filosofia foi proibida em Utrecht (1642), em Leyden (1648) e, finalmente, nos Países Baixos (1656).

A pena de Descartes, como a de Galileu, significava, sem dúvida, uma grave advertência, que não podia passar despercebida nos países católicos e que afetaria, de alguma maneira, a livre reflexão sobre a formação e estrutura da Terra. Sem dúvida, ele tinha que ser cuidadoso na reflexão científica sobre estes temas e era particularmente perigoso postular universos formados a partir de um caos original e submetidos a leis naturais estabelecidas por Deus e que nem mesmo Ele poderia modificar. O relato do Gênesis se impunha fortemente como ponto de partida para explicar a história da Terra e a ele deveriam adequar-se todas as interpretações que se realizavam.

\section{A Nova Ciência e o Estudo da Terra}

A condenação imposta a Galileu e as observações ante a obra de Descartes não podiam evitar que a nova forma de raciocinar, típica da revolução científica, estivesse presente, também, na reflexão sobre a natureza terrestre e sobre as eventuais mudanças que podia haver-se produzido nela.

Nos países afetados pela Reforma, a maior tolerância doutrinal permitia, às vezes, atrevidas tomadas de posição na linha adotada por Francis Bacon sobre a necessidade de separar a ciência e as crenças religiosas, e sobre a necessidade de limitar a reflexão científica a tudo aquilo que pudesse ser observado e experimentado. A figura do geógrafo Bernhard Varênio é, neste sentido, particularmente significativa.

Em sua "Geographia generalis", publicada em Amsterdam em 1650, Varênio declara decididamente que "a geografia não se preocupa com as opiniões dos antigos nem tem necessidade de recorrer aos milagres para explicar as propriedades da Terra" (1650, cap. VII, prop. III) Opondo-se aos que imaginavam sistemas especulativos, e, neste sentido, também explicitamente a Descartes, defende que a falta de observações impossibilita a asseguração da constituição interior de nosso planeta (1650, I, VII, prop. V). Na obra de Varênio não existem ecos da racionalização teológica ou especulativa, já que somente aceita a explicação racional e a argumentação do fato observado. Baseado, portanto, nas suas observações, foi capaz de enumerar as distintas camadas da Terra até uma profundidade de 232 pés, aproveitando uma perfuração realizada em Amsterdam (1650, cap. VII, prop. VII), mas se absteve de extrapolar esses resultados e de deduzir hipóteses sobre os estratos mais profundos não conhecidos. Por último, como característica também típica do novo espírito científico, está também ausente de qualquer interpretação finalista sobre as características do relevo ou da condensação das nuvens nas montanhas, mas não pensa que o Criador tenha colocado estas para produzir tal fenômeno.

Este mesmo espírito científico, que valoriza a concisão e a claridade e que renega a erudição e a autoridade dos clássicos, podia ser desenvolvido nos países católicos. A obra do finlandês Nicollas Steensen, ou Stenon, é bem significativa. Em seu "De sólido intra solidum naturaliter contento" (1669), publicada em Florença, dedicada ao duque de Toscana Fernando II e publicada com todas as licenças episcopais e do Santo Ofício, Stenon era outro representante da nova ciência e dá provas de uma grande ousadia intelectual. Sua visão da Terra era quase que completamente moderna, exceto naquelas partes que tocavam aos obstáculos fundamentais derivados do relato bíblico: a limitada cronologia da história terrestre 
e a existência do Dilúvio.

Stenon se opõe à idéia de que todas as montanhas existiram desde o princípio do mundo e possui uma concepção de relevo terrestre extremamente dinâmica: as montanhas eram formadas por estratos e estes podem elevar-se violentamente como resultado da combustão de gases ou do vulcanismo, e fundir-se por escavação dos estratos inferiores. Neste último caso podem ser adotadas diferentes posições em razão da diversidade das cavidades subterrâneas: reconheceu claramente o processo de sedimentação ao afirmar que "os estratos da Terra depositam-se pela ação de um fluído" (Stenon, 1669, 26) e dedicou essencialmente sua obra a estudar "os sólidos naturalmente contidos dentro de outros sólidos", ou seja, os cristais e as petrificações de restos orgânicos que podem observar-se nas formações rochosas, sendo neste sentido o criador da cristalografia.

A alteração na posição dos estratos é a principal causa da formação dos montes e é comprovada, segundo Stenon, por indícios diversos, tais como a existência de partes planas nos cumes de algumas montanhas, a freqüente disposição paralela dos estratos que formam um relevo e a presença desta mesma nos contornos dos vales escavados pelos rios, e a inclinação que às vezes se observa em outros países. Stenon baseou suas idéias em uma correta observação de diversas particularidades da crosta terrestre e chegou a referir a existência de uma história da Terra através da racionalização indutiva originada pela disposição das rochas. Atreveu-se, inclusive, a aplicar suas teorias a um grande espaço geográfico concreto, o da região de Toscana, como forma de afronta que revela um novo espírito científico, e a apresentar, sobre a evolução do relevo de dita região, um modelo gráfico que, por sua claridade e elegância, é plenamente moderno. O fundamento de sua aplicação está expresso com estas concisas palavras: "de que forma as condições presentes de uma coisa descobrem a condição passada de dita coisa põe-se em manifesto em Toscana, na qual as desigualdades da superfície observadas em sua aparência atual contêm nelas mesmas os sinais de diferentes mudanças" (Stenon, 1669, 67). A figura reproduz dito esquema gráfico e as explicações do mesmo Stenon a cada uma das seis fases que distingue.

\section{A teorização de Stenon é} necessariamente catastrófica pela necessidade de aceitar a curta cronologia terrestre baseada na interpretação eclesiástica do relato bíblico. Por outra parte, apesar do rigoroso espírito científico e da ousadia intelectual de seu autor, dito relato estava sempre presente como marco de referência inevitável, e Stenon se vê obrigado a justificar sua atrevida interpretação: "porém para que ninguém se alarme da novidade de meu ponto de vista, sendo em poucas palavras mostradas de acordo com a Natureza e com a Escritura". Essa condição se refere a cada uma das seis fases de seu esquema evolutivo, e vale a pena deter-se em seu raciocínio, porque mostra uma maneira de resolver um grande problema intelectual por parte de um grande cientista do século XVII.

Segundo Stenon, em alguns pontos a natureza e a Escritura apresentavam uma explicita e plena concordância. Assim, com referência à primeira fase, em que todas as coisas estavam cobertas pela água, a existência de um fluído aquoso em movimento, em que animais e plantas não existiam e que o fluído aquoso cobria todas as coisas, aparece no Gênesis, e, de forma natural, é comprovada pelas camadas geológicas das montanhas, livres de todo material heterogêneo, ou seja, livres de petrificações orgânicas. Outras vezes a natureza é silenciosa; porém a Escritura diz como ocorre na segunda fase, em que a Terra é plana e seca. Sobre a terceira fase, nem a Escritura nem a natureza dizem muita coisa; a natureza somente diz que a sua diversidade é grande, já que a Escritura faz menção de montanhas no tempo da inundação; mas sobre o fato de que, no momento da formação de ditas montanhas e sobre elas os vales, estes teriam a mesma profundidade que tinham no começo do dilúvio, nada é relatado nem pela natureza 
nem pela Escritura.

Sobre a quarta fase, quando todas as coisas tornaram-se novamente água, a concordância entre a natureza e a Escritura parece a princípio mais difícil, mas também pode ser comprovada: a observação da natureza mostra que existem restos marinhos a várias centenas de metros acima do nível atual dos oceanos, o que comprova que todas as áreas foram cobertas pelas águas por uma segunda vez. Para Stenon, esta inundação se produziu no dilúvio, cuja explicação racional é facilmente assimilada a partir da aceitação de vários supostos: que a altura das montanhas que foi imersa pelo dilúvio não era necessariamente a mesma que as montanhas atuais, que existem grandes cavernas subterrâneas que podiam conter água, e que o fogo interior pôde aquecer estes reservatórios e produzir vapor que originaria grandes chuvas. De qualquer modo, os vales mais profundos se formariam, então, pela força da circulação das águas, como se mostra pela existência de depósitos marinhos em muitos vales interiores afastados do mar.

A quinta fase, em que a terra estava de novo plana e seca após o dilúvio é provada pela natureza e não negada pela Escritura, já que esta não diz nada sobre a história das nações em um período imediatamente posterior à inundação. Sabe-se que os rios enviam a cada ano grandes quantidades de sedimentos ao mar, e que algumas regiões litorâneas anteriormente pantanosas eram secas, como indica o testemunho de muitas histórias gregas. Por último, a sexta fase é evidente aos sentidos. Stenon crê que ainda que não se conheça a evolução da Terra nos últimos 4.000 anos, resulta-se evidente que ela sofreu muitas mudanças, como se comprova, também, parcialmente, pelas notícias e relatos dos antigos.

Com Varênio e Stenon encontramos dois cientistas modernos reflexionando livremente sobre a estrutura e a história da Terra, afetados de maneiras diversas, não somente no país em que escreviam, mas, sobretudo, pela índole de sua obra, pelo relato bíblico. A obra deste último autor mostra que, apesar da condenação de Galileu e de Descartes, era possível desenvolver-se nos países católicos uma reflexão sobre a Terra de acordo com o espírito científico dos novos tempos.

Cabe perguntar-se, agora, sobre quais podiam ser os representantes desta linha de pensamento na ciência espanhola do século XVII. A resposta é, no momento, difícil e exige o início de investigações sistemáticas sobre a história da geologia hispânica deste período. Na segunda metade desse século, deve-se realizar essa atitude na obra de técnicos que, de algum modo, se vêm obrigados a confrontar-se com a questão do relevo terrestre, tais como os engenheiros, mineiros, alguns naturalistas, navegadores, geógrafos, e, desde os anos de 1680 , os membros do movimento inovador que adotam claramente o espírito científico dos novos tempos, ainda mais no que se refere às suas idéias sobre a Terra e sistemas imaginados externamente, superando a observação própria e original.

\section{Uma Terra Envelhecida por Iniqüidades}

As obras dos autores antes citados (Descartes, Varênio e Stenon) mostraram a adiantada aplicação dos princípios da revolução científica para com a reflexão sobre a Terra, ainda que os obstáculos que opunham a dita reflexão estivessem voltados à validade do relato bíblico. Na realidade, a importância que para os europeus do século XVII tinha o sistema de crenças, internamente aceita ou externamente imposto, determina que os debates teológicos que tendiam a interpretar tal relato tenham uma importância extrema para o desenvolvimento das idéias geológicas.

Dito debate involveu ativamente não somente os eclesiásticos, mas também a humanistas de interesses muito diversos (filósofos, historiadores, juristas, entre outros), assim como a muitos dos mais importantes cientistas do momento. As questões eram muito 
numerosas. No caminho até a geologia científica, o debate puramente teológico, as discussões filosóficas e históricas e os resultados da observação empírica aparecem indissoluvelmente associados. Os dados eruditos ou empíricos reunidos acerca da erosão do relevo ou do transporte e depósitos de sedimentos, assim como a descoberta de restos orgânicos petrificados não podiam ser corretamente interpretados até que existissem novos e adequados marcos conceituais. Estas questões foram-se perfilando através das disputas entre os conservadores e modernos, o lugar do inferno e do paraíso terrestre, o significado e o alcance do castigo de Deus aos homens, o mecanismo através do qual se produziu o dilúvio e sua extensão ao continente americano, a existência de homens gigantes ou muito velhos no passado, a origem dos índios americanos ou o conceito de providência e a possibilidade de milagre em um mundo regido pelas leis naturais.

Alguns pontos de vista deste complexo debate, e, em particular, sobre o problema do dilúvio e de seus efeitos sobre a terra prédiluvial adquiriram uma importância decisiva na história da geologia, e se relacionam ademais com outros debates intelectuais da época, como por exemplo, no que se refere ao confronto entre uma concepção do mundo otimista e outra pessimista.

No século XVII, a tese sobre a Terra em decadência começou a ter um grande número de adeptos a partir de pressupostos teológicos sobre o significado do pecado dos homens e sobre o alcance da misericórdia divina. O centro da polêmica estava na interpretação do significado do castigo que Deus havia imposto aos homens pelo pecado dos sucessores de Adão e Eva. Que o dilúvio havia sido enviado para exterminá-los e que a misericórdia divina somente havia salvado a Noé e a sua família e a um casal de cada espécie, era indubitável a partir do texto do Gênesis. Porém, cabia perguntar-se se a mesma terra havia sido também alcançada pelo castigo.
Os homens do Renascimento iniciaram a perguntar-se sobre a inundação e seus efeitos reais na superfície terrestre, e o tema seguiu preocupando no século XVII. Antes, apareceu o problema de sua universalidade e, em particular, o de sua extensão na América, além dos efeitos que se havia produzido no relevo. E é daqui de onde surgiu a necessidade de elaborar interpretações racionais que, apoiando-se nos dados que então possuíam, deram conta destes efeitos, abrindo uma importante brecha para a aceitação da idéia de dinâmica da superfície terrestre.

Esse debate científico-teológico se produziu tanto nos países protestantes como nos católicos, ainda que nestes últimos o debate se fizesse com maiores dificuldades, quando em 1686 se condenou as leis de Vosio sobre a espacialidade restringida do dilúvio. Porém na Espanha, em meados do século XVII, o debate pôde-se realizar, surgindo uma tese verdadeiramente revolucionária, que teria grande impacto nos anos seguintes. Refiro-me à tese do humanista José Antônio González de Salas, exposta, primeiramente, em alguns comentários inseridos em sua tradução do "Compêndio Geográphico" de Pomponio Mela (1644), difundidos mais tarde em toda Europa através de sua obra "De duplici viventium Terra dissertatio paradoxica" (Leyden, 1650).

O autor acha estranho um texto do livro IV de Esdras, em se que diz que as águas que existiam no princípio da Criação se retiraram no terceiro dia para ficar em um sétimo da superfície do Globo, deixando descobertas e secas as outras seis partes. A citação de Esdras não havia sido um descobrimento original do espanhol. Desde o Renascimento, esta paisagem, que logo seria considerada de um livro sagrado, era de um lugar comum da Europa, porém, seu interesse não diminui por isto. Este texto contradizia claramente a tese de Aristóteles, que aceitava que o espaço coberto pelas águas era dez vezes maior que o da Terra. O descobrimento da América havia desvalorizado a opinião de Aristóteles, mas, de todas as maneiras, as proporções terra/água 
não eram as que apontavam o texto bíblico. A necessidade de aceitar como indubitável a paisagem da Escritura afetava toda a reflexão sobre a estrutura superficial do Globo terrestre ou as idéias sobre a história da Terra. Em efeito, somente havia duas soluções: ou existiam terras desconhecidas de grande extensão, ou a configuração das terras e dos mares havia experimentado mudanças. A primeira hipótese conduzia a aceitar a existência de um grande continente não conhecido no globo no hemisfério sul. Desta maneira, a partir do texto bíblico, poderia-se concluir a existência de um imenso continente austral, ainda por descobrir. Foi a hipótese apoiada por numerosos naturalistas e geógrafos, que levava no século XVIII a Buffon defender a existência desta Terra Incógnita.

A segunda hipótese obrigava a reinterpretação da história da Terra, aceitando a existência de mudanças importantes na configuração da superfície. O caminho que seguiu o erudito espanhol em 1644 e que o conduziu a elaborar sua tese sobre as diferenças entre a terra pré e pós-diluvial.

Uma série de argumentos permite a González de Sala concluir que nas vezes que Deus quis castigar os homens "sempre estendeu sua indignação também às habitações humanas, procedendo assim de modo tão absoluto que não deixava nem mesmo um mínimo vestígio, nem um indício leve, de como houvesse sido o passado humano".

Desta maneira castigou Deus no dilúvio os homens e a terra. "Os homens que padeceram então, não se recuperaram para que se povoasse o Mundo: outros de raízes diferentes se procriaram, precedidos daqueles que foram destinados às águas". De maneira semelhante, "outra Terra havia assim de suceder a primeira, quando se inundasse, descobrindo depois uma nova porção, e sua praga, também assim assinalada, seria expulsa de seu mesmo Globo". Houvera resultado excessivo até que "quando seu artífice determinava a renovação do Mundo, retornava a dar à espécie humana habitação em solo próprio, ainda em meio a iniqüidades antigas". Tão pouco havia sido lógico que: "depois de tanto acréscimo da corrupção humana, pôde-se julgar bem precavido ao perigo da reincidência, volvendo a mesma Sabedoria e colocando o homem nas habitações, outra vez podendo comunicar-lhe a maldade que tinha contraído".

A conclusão desta argumentação teológica é clara: a Terra teria necessariamente que mudar como resultado do castigo divino. 0 trabalho do erudito madrilenho se dedica a uma tarefa que pode parecer-nos surpreendente, mas que serve para apoiar sua tese. Trata-se da tentativa de reconstruir a geografia do mundo por Adão e Eva e seus descendentes. A obra de González de Salas demonstra que a fidelidade ao relato bíblico podia ser unida a uma discussão racional do mesmo, e que a argumentação erudita podia conduzir à racionalização de caminhos inesperados. Outro exemplo interessante disto é a realização também de discussões que se davam em torno da localização exata do paraíso terrestre, nas quais foram temas de importantes hipóteses de autores espanhóis como León Pinelo (Capel, 1985).

\section{A Teoria Sacra da Terra}

No final do século XVII, a tese da decadência da Terra formulou-se de maneira explícita e decidida acentuando a importância da destruição. A Terra pós-diluvial converte-se em ruína. Foi na Grã-Bretanha e na Europa Central onde mais claramente se elaborou, nos decênios finais dos seiscentos e no primeiro dos setecentos, esta interpretação da história terrestre em que o dilúvio mosaico se converte em um fator de ruína e destruição irreversível para o nosso planeta.

A polêmica do dilúvio, de sua produção natural e de seus efeitos converteu-se, nesse momento, em um problema científico de primeira magnitude. A obra do clérigo inglês, Thomas Burnet, "Telluris Theoria Sacra" (Londres, 1681), propôs a idéia de uma terra plana pré-diluvial 
transtornada pelo dilúvio, tese que tem diversos precedentes na Espanha do século XVI.

A tentativa dos que, como Burnet e antes Descartes, se esforçavam por interpretar claramente a história da Terra teria perigos insuspeitáveis. A ênfase nas causas mecânicas podia apoiar a posição dos ateus, por argumentos a favor do mundo eterno, de um mundo formado por causas materiais com a intervenção do azar. Por isso, apesar do comportamento eclesiástico do autor, o sistema de Burnet não tardou em ser identificado juntamente com o das correntes ímpias, materialistas e atéias que exaltavam "o cego mecanicismo e o cego acaso", em Palavras de Richard Bentley dedicadas precisamente a caracterizar a concepção burnetiana.

Não é estranho, por tudo isso, que a teoria de Burnet dera lugar imediatamente a uma grande polêmica científico-teológica na GrãBretanha. Em dez edições de sua obra, é mostrado o êxito da interpretação de Burnet, que foi inclusive aprovada por Newton em 1680, antes de sua publicação. Desde logo, a interpretação de Burnet não foi única, e nos anos finais desse século, com o calor das polêmicas que se suscitou, apareceram outras interpretações como a de John Woodward e a de William Whiston. Ainda que esta última diferisse no detalhe da explicação, coincidia com a de Burnet em referir-se ao relato bíblico e em propor uma interpretação científica e racional. Para Whiston, a narração bíblica não é um relato vulgar, mas que precisava ser substituída por uma interpretação científica mais rigorosa. A sua interpretação foi a de uma terra formada pelo resfriamento de uma nebulosa e de um dilúvio provocado pela proximidade da Terra com a cauda de um cometa, que originaria a elevação das águas interiores e marinhas; e a aceitação do possível desaparecimento da Terra no futuro com o choque de um outro cometa.

As reações ante essas interpretações racionais da história da Terra foram de dois tipos: a dos eclesiásticos, que mostravam a incompatibilidade dessas teses com o relato bíblico; e a dos cientistas, que punham em manifesto o pouco rigor científico de suas idéias, pedindo respeito ao relato bíblico. O interessante agora é destacar que estes cientistas eram nada menos que os ligados ao círculo de Newton; os quais, liderados pelo próprio Newton, coincidiam suas idéias com a dos eclesiásticos em defender a validade do relato bíblico, e a existência de um Ser criador do universo, se opondo à idéia de que a Escritura podia ser uma simples descrição fictícia. O relato bíblico, com toda sua carga de acontecimentos milagrosos, expôs-se contra os livre-pensadores ingleses que aceitavam o destino ou postulavam um mundo existente desde toda a eternidade. Frente às concepções que aceitavam a existência de um caos original ou de uma decadência progressiva, defendeuse a concepção de um mundo harmonioso planejado pelo Criador. Os círculos newtonianos enfrentaram-se abertamente à tese de Burnet, tanto no que se refere à sua concepção da história da Terra, como às pretensões que teria o clérigo de interpretar livre e racionalmente o relato bíblico. Apareceu, assim, no final do século XVII, na Grã-Bretanha, um bom número de publicações contra Burnet, defendendo a veracidade e presença da narração do Gênesis, e defendendo Moisés.

Tratava-se, também, de defender a religião e mostrar a validade do relato bíblico, cuja racionalização se considerava desnecessária e impossível. Assim, se considerava que o caráter milagroso do dilúvio demonstrava-se pelo fato de que fora totalmente impossível de ser produzido por causas naturais. Era algo maligno aplicar a ciência à religião, já que, se não se aceitava que Deus podia livremente realizar ações milagrosas como o dilúvio, abria-se a idéia da tese de que Deus era supérfluo, incentivando o ateísmo. A isto se unia, como novo elemento de separação da ciência e da religião, a aceitação de alguns cientistas de uma visão teleológica e antropomórfica do mundo, ausente em Burnet e em Whiston: a Terra não podia ser produto do acaso, mas o resultado de um plano divino e produto de Sua onipotência e sabedoria, para 
melhor serviço do homem. Tratava-se, por sua vez, de uma luta entre posições científicas e na defesa da fé. E o sistema de Burnet estava no centro dessas polêmicas porque parecia colaborar, de forma particularmente perigosa, à impiedade e ao ateísmo, concentrando sua ênfase na ruína da Terra, opondo-se à noção de um mundo harmonioso criado para a morada do homem.

A tese da ruína da Terra pelo Dilúvio não apareceu somente na Grã-Bretanha. Nos mesmos anos em que escrevia Burnet, tudo, inclusive a Bíblia, começa a ser submetido ao exame da razão. Alguns se atrevem a insinuar que a Sagrada Escritura está escrita em linguagem alegórica ou fabulosa, e que é preciso interpretá-la racionalmente. Até fins do século XVII, muitos protestantes e, também, alguns católicos se lançam ao desafio de realizar esta interpretação, de examinar as contradições dos textos sagrados, de separar o que corresponde propriamente à palavra divina.

Não é estranho que neste ambiente surgira também o desejo de elaborar uma "física sagrada ou história natural da Bíblia", ou seja, uma interpretação do relato bíblico à luz dos conhecimentos científicos da época. Esta foi a tarefa à qual se dedicou o médico e engenheiro suíço Johann J. Scheuchzer (1672-1733), professor de matemáticas em Zurich, em uma magna obra que continua em muitos aspectos a da literatura hexameral. Sua "Physica Sacra" (1721) recorre às experiências acumuladas pelo autor nos cursos dedicados a explicar os textos da história sagrada à luz dos princípios da filosofia moderna. Em aspectos bem significativos, o exame a que se submeteu Scheuchzer o texto sagrado, contrastando-o com com suas próprias observações nas montanhas dos Alpes, o fez chegar à conclusão da ruína do mundo por meio do dilúvio.

\section{A Especulação Humanista Sobre a Estrutura da Terra}

A discussão sobre a universalidade do dilúvio e seus efeitos sobre a superfície da Terra consolidou-se nos países católicos com muito menor liberdade do que como se havia efetuado nos países protestantes.

Algo semelhante ocorreu com as teses de Burnet e de outros cientistas ingleses a que nos havemos referido. Uma interpretação da Bíblia tão livre, como a proposta por alguns desses autores, não era aceitável para a Igreja de Roma, e disto eram bem conscientes os cientistas católicos. Muito mais na Espanha, de onde a presença da Inquisição era mais severa, provocando uma cuidadosa autocensura nos intelectuais que refletiam sobre temas indiscutivelmente conflitivos.

$\mathrm{Na}$ Espanha, as teses de Burnet, associadas geralmente às de Woodward, e logo depois, também às de Whiston, foram objeto geralmente de uma oposição formal por parte dos poucos cientistas que aludiram a elas durante a primeira metade do século XVIII. Com freqüência, as referências que possuíam também eram indiretas e procediam de outros autores que as haviam resumido, como por exemplo, Buffon. Mas, apesar destas limitações, pôde-se afirmar que existiu um debate sobre essas teses na Espanha nas primeiras décadas do século XVIII (Capel, 1985, p. 120), limitado pela forte influência da censura religiosa.

Maior eco teve em nosso país outras teorizações que não afetavam diretamente a narração bíblica. Referimo-nos às especulações realizadas nos países católicos sobre a estrutura interior da Terra.

No princípio do século XVII o astrônomo francês Jean Baptiste-Morin havia dedicado atenção ao tema em sua "Nova Mundi sublunaris anatomia" (Paris, 1610), na qual criticava a teoria aristotélica dos elementos. Distinguia três partes da esfera terrestre: a superior, contígua ao ar, que teria uma espessura de 80 exapodos, sendo que podiam chegar a 100 ou até 150, segundo as características do terreno na superfície; a região intermediária, cuja espessura era indeterminável, sendo que as temperaturas aumentavam consideravelmente; e a inferior, situada na parte central do globo, e 
que por estar proposta à região do ar, que é quente e úmida, devia ser fria e seca, e também estéril e incapaz de geração alguma de vida. Desta tese repercutiu na Espanha José Vicente del Olmo, em sua "Nueva descripción del Orbe de la Tierra" (1681), ainda que a título puramente erudito e ilustrador, já que sua opinião parece tender mais para o sistema do padre Kircher.

Este último coincidia suas idéias com as de outros autores espanhóis, já que o sistema de Kircher foi seguramente o mais influente sistema na Espanha dos últimos três decênios do século XVII e dos primeiros do século XVIII.

O "Mundus subterraneus" (1665), do jesuíta Athanasius Kircher, combina as concepções organicistas, de tradição platônica e hermética, com um bom conhecimento da filosofia aristotélica, tão importante na "Ratio Studiorum" jesuíta, e com uma vasta erudição típica do humanismo do século XVII e do espírito polimático de seu autor, em uma das mais ambiciosas tentativas que se realizou nesse século para apresentar um sistema coerente da estrutura interior de nosso planeta e seus pirofilácios, hidrofilácios e aerofilácios, apresentados belamente em um sistema de idéias gráficas, que se converteram em um prestigioso modelo da constituição terrestre (Capel, 1980 e Sierra, 1981). Sua obra foi amplamente conhecida na Espanha, não somente através de seus irmãos de religião, mas também por outros cientistas como Caramuel ou membros do movimento renovador valenciano. Todavia, em 1724 Diego de Torres e Villaroel utilizaram suas idéias, tomadas, sobretudo, de outra obra de Kircher, o "Iter Exctaticum celeste et terrestre" (1654), para apresentar uma ampla síntese de suas idéias em um livro de grande aceitação popular.

\section{Final}

Chegamos, assim, ao final deste trabalho e, sem dúvida, deixamos diversas questões que podiam haver sido também oportunas, tais como, dentre outras, a concorrência pelas petrificações ou, então, a questão do azar e da providência no mundo, que são de grandes implicações para o desenvolvimento da moderna geologia.

Porém não se trata de esgotar o tema, mas, sim, de mostrar algumas linhas através das quais se desenvolveu a reflexão sobre a Terra no período compreendido pelo Renascimento e começos do século XVIII, mostrando, ao mesmo tempo, de que forma o debate científico está intimamente relacionado com as crenças religiosas e com as idéias filosóficas herdadas da antiguidade ou propostas nesses anos. Através de um longo debate, que por sua vez era filosófico, teológico, filológico, histórico e científico, os Europeus dos séculos XVI e XVII começaram a aceitar que a Terra teria uma história e que esta não estava narrada na Escritura, que podia ser reconhecida nos "vestígios" e "monumentos" da natureza. Uma terminologia que já, por si mesma, mostra a íntima relação que existia naquela época entre a história civil e a história natural.

\section{Bibliografia}

CAPEL, H. Naturaleza y cultura en los orígenes de la geología española In: LAFUENTE, A. \& SALDAÑA, J. J. Historia de las ciencias. Madrid : Consejo superior de investigaciones cientificas, 1987. pp. 167 - 195. 
